
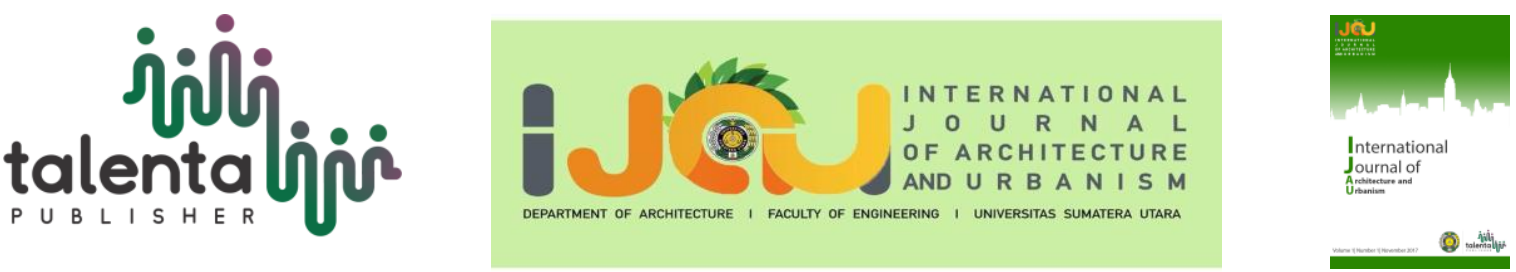

\title{
Local Wisdom-Based on Development of the Environment and Atmosphere Aspect of Berastagi Night Tourism
}

\author{
Selly Veronica ${ }^{1,2}$, Nurlisa Ginting ${ }^{1,2,3}$, and Amy Marisa ${ }^{1}$ \\ ${ }^{1}$ Master's Degree Program of Architecture, Universitas Sumatera Utara, Medan, Indonesia \\ ${ }^{2}$ Monitoring Centre for Sustainable Tourism Observatory Universitas Sumatera Utara, Medan,Indonesia \\ ${ }^{3}$ Toba Lake \& Sustainable Tourism Working Group, Universitas Sumatera Utara, Medan, Indonesia
}

\begin{abstract}
Nowadays, tourism has an important place in urban development, where every city competes to improve their tourism. Night tourism, as the new strategy in tourism development, needs to be given attention from the stakeholder. The two most important aspects of the night tourism development are environmental and night atmosphere. Increasing the aspect of night tourism cannot be separated from the local wisdom-based. Berastagi is the most popular tourist destination in Karo Regency, which has a night tourism destination. Not only it, but Berastagi also has an authentic culture from the Karonessse tradition. Unfortunately, both of these potentials have not developed yet as the strength of tourist attraction in Berastagi. This paper aims to find how are the development of the environment and atmosphere aspect of Berastagi Night Tourism based on local wisdom. This research used a descriptive qualitative method which analyzes data collected by field observation and depth interview. The study shows that involving local wisdom in developing the environment and night atmosphere can build a specific identity for the town night tourism.
\end{abstract}

Keyword: local wisdom; environment; night atmosphere; night tourism; Berastagi

Received 28-06-2020 | Revised 10-07-2020 | Accepted 29-07-2020

\section{Introduction}

Nighttime tourism has a specific image that can give unique and different experiences than day time tourism [1]. Nowadays, night tourism becomes a trend because of the tourist's behavior, which spending their night time enjoying some leisure activities such as shopping, sightseeing, or culinary hunting while traveling to maximize their time when visiting someplace [2]-[4]. Night tourism development also presents to become one of the innovative strategies for the city to compete in the tourism sector [5]. There are four main elements in developing night tourism, i.e., economic, social, environmental, and night atmosphere [6]. Environment and night

\footnotetext{
*Corresponding author at: Master's Degree Program of Architecture, Faculty of Engineering, Universitas Sumatera Utara, Jalan Perpustakaan Gedung J07, Medan 20155, Indonesia
}

E-mail address: selly.veronica@students.usu.ac.id 
atmosphere is the critical element of night tourism which build the tourist perception for the image of the destination [1]. However, the development of night tourism cannot be separated from the effect of the local wisdom of the local community for attracting tourists [7].

Berastagi, with the high number of tourist arrival, is very potential to develop as the night tourism destination. Based on the data from the Government Tourism Office of Karo, Regency found that Berastagi is the most popular tourist destination in the area. Berastagi has the beauty of nature and the freshness of the air with a strong uniqueness from the Karo ethnic culture. The variety of tourist attractions offered in Berastagi causes this town to become a tourist destination visited by many domestic and foreign tourists [8]. Increasing the environment and night atmosphere aspect in the Berastagi night tourism must be developed with local wisdom.

Previous studies mostly examined night tourism in terms of destination lighting as an attraction [2], [7], [9]; tourist behavior when enjoying the night time [3], [4]; and benefit for the local community and development [10], [11]. It showed there are only a few previous night tourism studies that were analyzed with the local wisdom approach. This study aims to find the environment and night atmosphere aspect on night tourism development in Berastagi based on local wisdom.

\section{Literature Review}

Developing night tourism in the city can be part of increasing the value of land use by using the open space as the tourism destination in the night [10]. The darkness at nighttime created a negative image, and it caused the development of night tourism must be planned opportunely and considered for tourist security [1], [11], [12]. The presence of proper lighting on night tourism not only provides security but also creates a visual effect for the surrounding area. The Local traditional ornament used in shaping the aesthetics of the light in night tourism will increase the image of the city [7], [13].

Urban space experiences, festivals, scheme regeneration, night tours, and theoretical ideas shape the night atmosphere of a city that manifests the real formation. Turning on the night atmosphere is also one of the innovations in utilizing the area, which is the solution to planning a city again [7]. One of the tourist attractions that interest tourists are night tours. Vernacular buildings and environmental values owned by rural areas are also attractions that provide new experiences for tourists [14]. Night tourism activities that are containing the local life become attractive tourist attractions. Diverse activities and a friendly atmosphere are the main factors for tourists to choose places to enjoy their time. Shopping, eating, playing games, and feeling indigenous customs and culture provide new experiences for tourists by exploring part of the local community [15]. 
Nighttime atmosphere offered a soft and charming impression that makes night tourism has its typical brand [1]. The scene from the shadow of a building row and the night city view attracts tourists. Proper development will improve night tourism activities such as seeing the night atmosphere and the beauty of nature, enjoying folklore, culinary tours, enjoying entertainment, and shopping. Diverse night tourism activities will provide various choices for tourists. Cultural performances on night tours can also be exciting attractions [9].

\section{Methods}

The study aims to find the environment and night atmosphere aspect in Berastagi night tourism, which develops with the local wisdom approach. For creating a precise and contextual result analysis, this paper used a descriptive qualitative method [16]. The primary data was collected by depth interview and field observation in the research area (Figure 1). Eight people who become the key respondent for depth interview was categorizing with based on the previous similar study [3]. The characteristic of the key respondent is academics, arts workers, community leaders, government, and tourism experts who know well about night tourism and local wisdom in Berastagi.

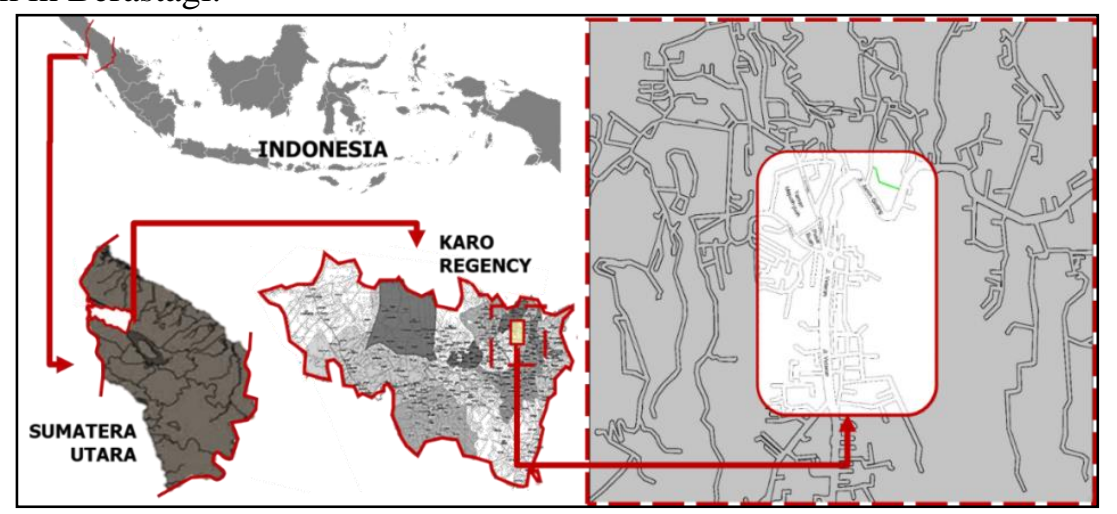

Figure 1 Research Area

There is two main theory used in this study, namely night tourism and local wisdom. In line with the purpose of this study, the theory of night tourism was limiting only the environment and nightscape aspect (Figure 2). The analysis started with the data tabulation, which interpreted by relating to the previous literature review. The results of data interpretation will be the basis of the formulation of the findings, conclusions, and recommendations of this study.

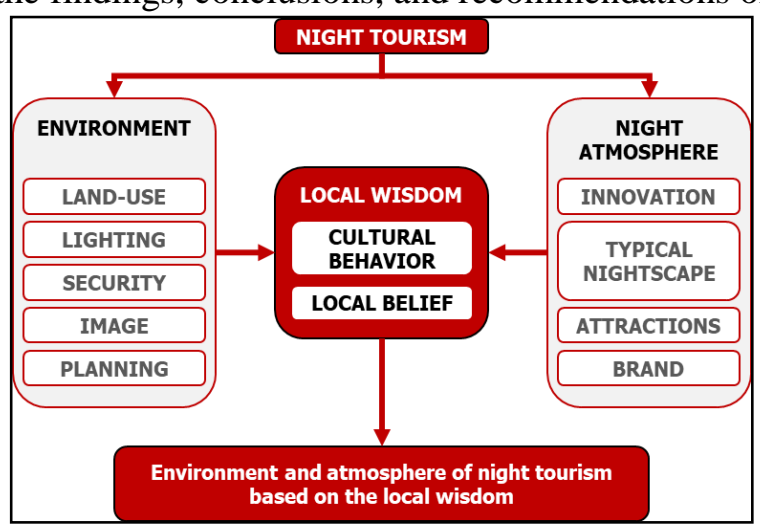

Figure 2 Research Area 


\section{$4 \quad$ Result and Discussion}

Based on the results of data collection that has been done through interviews with eight main sources and field observations, this chapter will discuss the analysis of these data. The development of night tourism based on local wisdom in Berastagi will be analyzed in two aspects, namely the environment and the night atmosphere.

\subsection{Environmental Aspect of Night Tourism Based on Local Wisdom}

The development of night tourism in Berastagi will affect the quality of the City Environment. Activities at night will increase the effectiveness of the environment, which is not only used for events during the day. Five indicators will be examined from the environmental aspects of night tourism, namely (1) Land Function, (2) Lighting, (3) Security, (4) Regional image; and (5) Planning.

\section{Land-use}

The presence of night tours will bring the city night time to life. These activities will not only turn on the night environment but can also increase the value and function of the surrounding land. Until now, the area provided for night tourism activities in the City of Berastagi is only along Veteran Street. The pedestrian path in this area functions as a culinary tourism destination that will only open starting at 18:00 WIB, which known as Pasar Kaget. Allotment of the downtown area that functions as a tourist at night can also be an effort in improving land functions, where land use does not only focus on daytime activities but continues into the evening [10]. This theory is related to what happened on Berastagi, and Veteran Street is the main route and centers of Berastagi. The pedestrian path that only functions as a means of pedestrians in accessing a place is functioned as a tourist destination at night (Figure 3). The presence of the Pasar Kaget also added to the value of the building behind it. Every stall that is opened in the Pasar Kaget area has been registered and had legality for temporary use. Traders are given an area of $3 \times 4$ meters for each stan with the note they must leave enough space for pedestrians. The business license also states that traders must be ready if the Pasar Kaget area will move to another place.

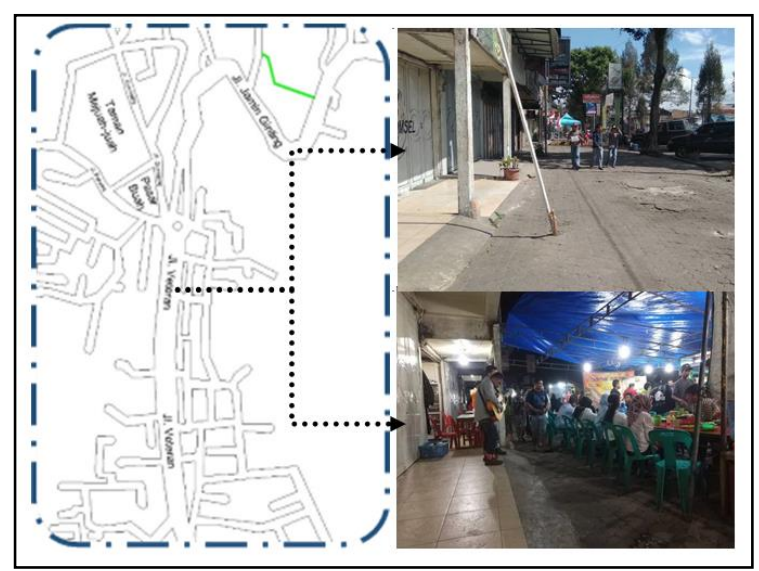

Figure 3 Pedestrian pathway functions during the day and night 
The presence of the Pasar Kaget right on the main access of Berastagi provides increased land use in the surrounding area. But on the other hand, its existence is a source of congestion on major and long holidays. The mobility of vehicles that must pass through Berastagi and the tourist vehicles that want to enjoy night tours in the Pasar Kaget have resulted in frequent congestion in the city. Moving the night tourism center to a place that is still part of the city center but can minimize the impact of congestion that occurs is one solution.

Empty land, such as a centralized parking lot, green open field, and open space, is a strategic area that can be processed into a city night tour [10]. Berastagi has a green open space that is still part of the city center, namely Taman Mejuah-juah. This park is also very potential if it is developed as a center for Berastagi night tourism activities. Aside from the spacious place, Taman Mejuah-juah has also been equipped with various facilities that can support the development of night tours such as open-stage, art buildings, and culinary centers. Utilization of the multi-purpose park as a night tourism destination will improve the land function of the area. Where Mejuah-juah Park can function as a city park during the day and become an attractive tourist destination at night.

\section{Lighting}

Nighttime tourism development must support by the presence of adequate lighting planning. Night conditions need the right lighting to provide comfort and safety for tourists. The local government also realized lighting planning needed on developing the night tourism. Lighting at night not only serves as a sense of security, but light can be part of the aesthetic. The darkness of the night presented with the lighting designed can change the image of the night and give aesthetic value to the city environment. The processing of local culture in the planning of night tourism lighting will provide a characteristic inherent in the image of the city. Used the local cultural aesthetics as forming elements of the design of night tourism lighting will give beauty to the region [7]. Involving local aesthetic values in night lighting planning has also been planned to be implemented in Berastagi. At this time, there is already city lighting that applies cultural elements in the form of traditional Karonesse house (Figure 4). The ethnical design will give a distinctive impression for tourists who see it, so that street lighting has not only practical value but also an aesthetic value for the city.

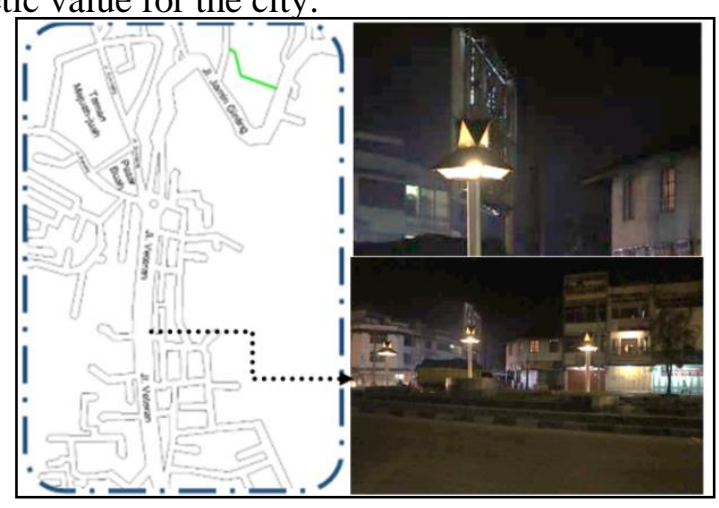

Figure 4 Design lighting that applies elements of Karonesse culture 
The overall area of the lighting of night tourism in Berastagi is still lacking. Lighting planning from the City Center of Berastagi to Bukit Gundaling is still in the planning stage. The inadequate lighting is also caused by the low attention of the government towards the development of night tourism in Berastagi City. Nighttime tourism activities must be supported by proper lighting because what is very important in the development of night tourism is the quality of light that offers a sense of security for tourists [13]. Night lighting in the Berastagi night tourism area is currently inadequate. Government efforts related to improving facilities and infrastructure to support the development of night tourism are still in the form of planning. To provide a sense of comfort and security for tourists, this needs to be improved. Inadequate lighting also occurs in Mejuah-juah Park. The absence of government focus on the development of this park as a night tourism destination affects the facilities provided.

\section{Security}

Nighttime tourism activities are prone to crime in a dark environment. But on the other hand, the development of planned night tourism supported by proper lighting can improve city security. The high activity until the evening in the city center can reduce the level of crime that may occur [10]. Berastagi has a safe environment for tourists who want to do night tours. Nevertheless, the development of Berastagi night tourism must be able to offer a sense of security for tourists who visit. So far, the leading cause of the Berastagi City area is safe for tourists is the involvement of local communities and cultural values that still apply.

Darkness nights are prone to crime; that is why security becomes a critical concern in the development of the night economy [12], [17]. At this time, the pattern of community life in Berastagi is still holding fast to the prevailing customs and kinship that closely provides security for the tourist area. The condition of the Berastagi City area that is not so large and the value of Karo tradition that is owned causes the community to get to know one another. The relationship in the community causes local people to be embarrassed to make a crime. Tourists can do night tours safely and comfortably in Berastagi. But even so, the security element cannot be ignored in the development of night tourism. The community itself is very supportive of improving security at night tourism activities. The presence of martial arts in the form of Karo martial arts, known as Ndikar can be one solution. Karo traditional and cultural institutions have scheduled to form an indigenous community consisting of ndikar to be able to be involved as part of the security of night tourism. Distinctive martial arts using typical ndikar clothing will be able to attract the attention of tourists who come.

Image

Spaces formed by the presence of night activities in an area can provide an image that is inherent in that area. Where the physical and social conditions of night tourism will affect the views of tourists on the image of the region [1], [2]. The lack of tourist destinations in Berastagi 
gives a lonely impression for tourists. By applying local culture in its planning, tourism activities will blend with the beauty found in the surrounding environment. The implementation of the local culture can provide an environment characteristic that becomes the image of the night tourism area [18]. Currently, there is no visible image in the development of the Berastagi city night tour. The only thing attached to tourists about the Berastagi night tourism is Pasar Kaget (Figure 5). There is no specific design or nuance application that shows the richness of Karo culture owned by the City of Berastagi in this region.

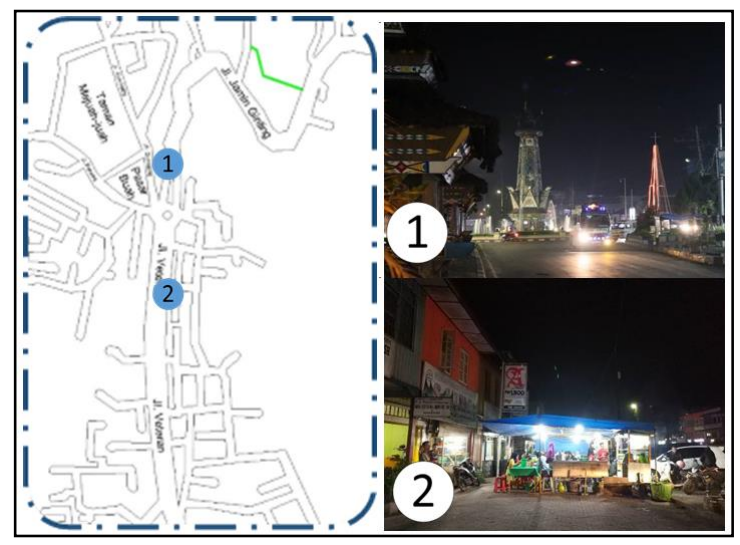

Figure 5 Forming the Image of Berastagi Night Tourism Area

Pasar Kaget, which is the only night destination for Berastagi, is only crowded on major holidays or during long holidays. On normal days this area becomes relatively quiet of tourists. Tourism activities in an area can be a factor that shapes the image of the region. Proper tourism planning will produce a good regional image of the city [4], [19]. But right now, the night tourism activities in Berastagi City, which are still in the form of culinary tourism, have not formed the image of the area.

Planning

Berastagi night tourism development must be held base on a steady plan. The right night tourism planning will create harmony with the environment and the lives of the surrounding community. The primary purpose of the planned night tourism is to increase the tourist's length of stay in Berastagi. Specific night tourism that will only available at night will force tourists to stay a night in Berastagi. The increase in tourist stays in Berastagi will provide growth in the regional economy. However, planning for the development of night tourism has not yet become a priority for the Karo District Government. The nighttime weather of Berastagi City is the reason for the Regional Government being pessimistic about the development of night tourism.

There are four influencing factors in the night tourism development namely, (1) the environment and weather that supports night tourism activities; (2) a wealth of night tourism attractions; (3) cultural richness and nightlife atmosphere; and (4) the presence of exciting places to shop at night [9]. The weather factor can indeed be one that is very influential in the development of night tourism. But the weather at Berastagi at night is not in extreme temperatures, and this 
should not be an obstacle for the Regional Government to develop night tourism. Especially at this time, the development of night tourism has become an urgent matter to be developed in the City of Berastagi.

In the development of night tourism, there needs to be necessary for planning. Based on the plan, the development of night tourism will provide maximum benefits for the local community [4]. Until now, there has been no careful planning from the Regional Government to develop night tourism in Berastagi City. At the same time, Berastagi must be able to survive amid the rapid competition of tourism in the area around Lake Toba, which is happening at this time. This should be able to encourage the Regional Government to develop the Berastagi City night tour. The planned development will provide an accurate picture for tourism entrepreneurs to take part in this. The proposed development of targeted night tourism will result in a transparent and characterized environment.

\subsection{Night Atmosphere Aspect of Night Tourism Based on Local Wisdom}

Night and daytime conditions of a city produce a different atmosphere that can be captured by tourists or people who see it. Daytime activities are synonymous with busy daily activities, while night time is generally used to find entertainment and rest. Analysis of aspects of the night atmosphere in the development of local wisdom-based night tourism in the City of Berastagi is based on four forming indicators, namely (1) Innovation; (2) Typical Nightscapes; (3) Attractions; and (4) Brand.

Innovation

Night tours can give a different impression to daytime for tourists, especially if the development presents innovations that provide characteristics and atmosphere that are different from the day. But it is unfortunate that until now, there has been no innovation carried out on Berastagi night tourism. Innovations made to enliven night tourism activities are still seasonal. The Regional Government has not tried to turn on night activities that run routinely. Berastagi City weather and natural conditions are often the reason for the pessimistic government in developing night tourism. The weather problem can be overcome by innovation in the management of night tourism that adjusted to the Berastagi environment condition.

Adjustment of the arrangement and products sold with the weather conditions in Berastagi can be an innovation in the development of night tourism. Innovation not only shapes as the offered product but also as the presentation of cultural arts performance. Reviving the atmosphere of the night is also one of the innovations in utilizing the region as a solution in planning a city again[7], [10]. Not in line with the theory, the Karo District Government has not made the development of night tourism a part of strategic planning. Passivity from the Local Government has an impact on the absence of innovation in the night tourism development carried out. Adjusting the arrangement as well as the product and cultural appearance offered to tourists is 
the kind of Innovations that possible to shape the night atmosphere of Berastagi. Distribution of product presentation schedules and cultural presence will make tourists curious about the various product and performances. Innovation will attract tourists and increase their desire to come again at another time and enjoy all the kind of culinary and traditional performance.

\section{Typical Nightscapes}

Different activities and different types of lighting that illuminate between day and night cause the atmosphere is also different. The atmosphere of the night, with the help of artificial light, has a distinctive picture that is different from the daytime. The atmosphere created at night provides added value for tourist destinations [5]. Relate to the literature, the typical image that appears at Berastagi night tourism is the impression of a relaxing and enjoyable time with family. An ideal description of the Berastagi City night tour that has the potential to be developed is culinary and cultural tourism.

To be able to offer something unique from the development of the Berastagi City grave tour, it is necessary first to identify what tourists want. Night tourists, especially those from Europe at night, will wish to a relaxing activity but can provide new experiences for them. Everything unique will be in high demand by tourists who come and visit. The richness of culinary specialties and Karo cultural performance arts are two things that are very potential to be developed. To strengthen the distinctive character of Berastagi night tourism is necessary to have a plan to be able to focus on the centralized attraction. The most strategic place to realize the program is Mejuah-juah Park. Where at this location, we can create a mini Karo District that can be enjoyed by tourists at night.

At night is the right time to be optimized as entertainment and travel. During the daytime, a city will be preoccupied with trading and office activities while the evening is a great time for entertainment and fun. Apart from daily activities cause night tours can be done more optimally in enjoying a different night atmosphere [13], [17]. The atmosphere of the night and day of the day can be processed to produce a different picture for tourists who visit. The offered thing on night tourism and the surrounding environmental conditions will provide a typical image of Berastagi night tourism. Daytime tourism has a description of natural tourism and souvenir shopping for tourists. At the same time, nighttime tourism is processed to produce an image of family culinary tourism and also the cultural tourism typical of the Karo tribe.

\section{Attraction}

Tourists generally do night tourism activities by shopping for food, walking around, or hunting for souvenirs. These tourist attractions already exist in the City of Berastagi, but this has not been developed and is very simple. Culinary attractions in the City of Berastagi is the Pasar Kaget, which is only open at night. Tourists can also enjoy various traditional coffee variants in 
the cafes in the City of Berastagi (Figure 6). Meanwhile, to look for souvenirs, tourists can visit the Fruit Market, but not all shops in the area are open until night.

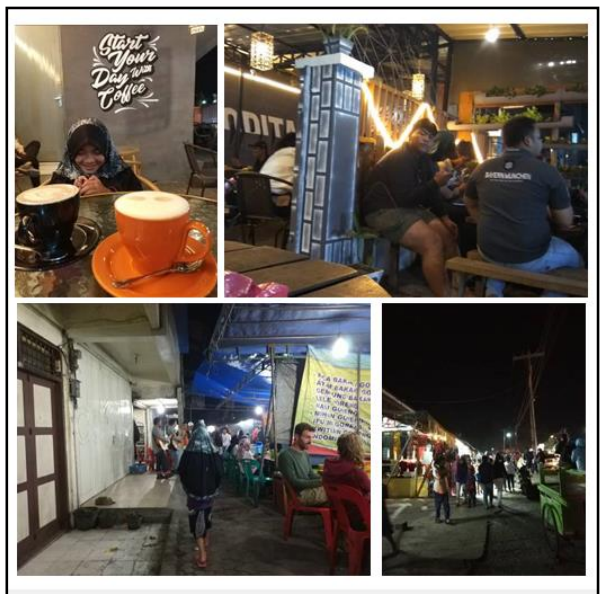

Figure 6 Berastagi Night Tourism Attractions

Each city has its way of providing nightly tourist attractions. The developed night tourist attraction must be adjusted to the type of tourist market that it wants. The drawback of the existing tourist attractions in the City of Berastagi at this time is that cultural activities have not been offered to tourists. Berastagi City has an influential culture and is identical to the Karo tribe, which is the majority ethnic group in this region. Karo dance, music, and other arts and culture have the potential to be developed into night tourism attractions that build the night atmosphere of Berastagi City.

The right development will increase night tourism activities such as seeing the night atmosphere and natural beauty, enjoying folklore, culinary tours, enjoying entertainment, and shopping. Diverse night tour activities will provide various choices for tourists. Cultural performances on night tours can also be exciting attractions [9], [16], [20]. Cultural appearance as one of the Berastagi night tourism attractions will give the impression and locality that can attract tourists. Two types of attractions that can be strengthened in the development of night tourism are culinary tourism and cultural tourism.

\section{Brand}

The visual appearance, social, and environmental atmosphere created, and the variety of products and performances can form a brand that is inherent in the minds of tourists towards an area of night tourism. The brand of night tours in Berastagi City until now is only in the form of a culinary attraction (Pasar Kaget). Based on the results of interviews conducted, the desired brand of Berastagi night tourism is Karo culture and culinary. The types of appearance and products offered by an evening tour, as well as the physical and social conditions of the area, will form a brand on night tours. 
Until now, the words of the development of night tourism for the general public will give a negative perception. Adjusting the night tourism activity with the local community norm will change the negative perception. The night atmosphere offered at night tourism produces a different impression in the daytime. The atmosphere will form the brand that is attached to the night tour of a city [1]. The concept from the theory can be applied in Berastagi, where the development of night tourism carried out on a cultural basis will produce a brand for these activities to be part of cultural recognition. The existing culinary brand in Berastagi night tourism can also be a very potent thing to develop.

\section{Conclusions}

The development of night tourism had an impact on improving the function of land use in the Berastagi, where tourism activities were not only focused on day time but continue into the evening. But the development of tourism tonight has not received particular attention yet by the local government. The minimum concentration from the local government affected the night tourism does not have proper lighting, and the potential had not supported with a strategic plan. Applying the Karonesse traditional ornament in the design of night tourism in Berastagi will increase the uniqueness of this place. Planning for developing night tourism is very important to do soon to increase the tourist length of stay in Berastagi.

Innovations in the development of night tourism in Berastagi have not yet been obtained, although various parties such as tourism actors, public figures, and the local traditional artist leaders have often provided input to local governments regarding this matter. Supposedly with the innovations carried out in the development of night tourism can create a memorable atmosphere for the Berastagi City night for tourists. Activities that are still minimal cause no typical picture that emerges from night tourism activities. This is also caused by the laying of the night tourism destinations that exist today, namely on Jl. Berastagi Veterans are still not right. The impression created from the arrangement of the Berastagi City night tour should be able to create a brand that is inherent in the thinking of tourists. The brand expected by each party to develop Berastagi City night tourism is culinary and cultural tourism. Future research is needed to find how is the effect of the night tourism brand on forming the image of the city. Local wisdom in an area should be pictured in the brand of night tourism in the city.

\section{REFERENCES}

[1] W. J. Huang and P. Wang, “'All that's best of dark and bright': Day and night perceptions of Hong Kong cityscape," Tour. Manag., 2018, doi: 10.1016/j.tourman.2017.12.006.

[2] S. H. Lee, S. C. Chang, J. S. Hou, and C. H. Lin, "Night market experience and image of temporary residents and foreign visitors," Int. J. Cult. Tour. Hosp. Res., 2008, doi: $10.1108 / 17506180810891591$.

[3] M. R. Ngesan and H. A. Karim, "Night Time Social Behavior in Urban Outdoor Spaces 
of Shah Alam," Procedia - Soc. Behav. Sci., 2012, doi: 10.1016/j.sbspro.2012.08.097.

[4] P. Wolifson, "Encountering The Night with Mobile Methods," Geogr. Rev., 2016, doi: 10.1111/j.1931-0846.2015.12154.x.

[5] A. L. O. Rodrigues, A. Rodrigues, and D. M. Peroff, "The Sky and Sustainable Tourism Development: A Case Study of a Dark Sky Reserve Implementation in Alqueva," Int. J. Tour. Res., 2015, doi: 10.1002/jtr.1987.

[6] S. Veronica, N. Ginting, and A. Marisa, "Kajian Aspek Ekonomi pada Wisata Malam Berastagi Berbasis Kearifan Lokal," in Prosiding Temu Ilmiah IPLBI 2019, 2019, pp. 36-43, doi: https://doi.org/10.32315/ti.8.c036.

[7] J. C. T. Baker, "Darkness, travel and landscape: India by fire- and starlight, c1820c1860," Environ. Plan. D Soc. Sp., 2015, doi: 10.1177/0263775815598083.

[8] N. Ginting, N. Vinky Rahman, A. Delianur Nasution, M. Nawawiy Loebis, and F. A. Sinaga, "Street furniture concept in Pasar Buah and Bukit Gundaling Based on place identity," in IOP Conference Series: Earth and Environmental Science, 2018, doi: $10.1088 / 1755-1315 / 126 / 1 / 012195$.

[9] Q. Guo, M. Lin, J. H. Meng, and J. L. Zhao, "The development of urban night tourism based on the nightscape lighting projects-A case study of Guangzhou," in Energy Procedia, 2011, doi: 10.1016/j.egypro.2011.03.083.

[10] S. A. Zaki and M. R. Ngesan, "A Future Town Redesigned - How Movement Pattern is Affected with the Concept of Night City," Procedia - Soc. Behav. Sci., 2012, doi: 10.1016/j.sbspro.2012.03.023.

[11] P. Wolifson and D. Drozdzewski, "Co-opting the Night: The Entrepreneurial Shift and Economic Imperative in NTE Planning," Urban Policy Res., 2017, doi: 10.1080/08111146.2016.1155983.

[12] D. Mercer and P. Mayfield, "City of the Spectacle: White Night Melbourne and the politics of public space,” Aust. Geogr., 2015, doi: 10.1080/00049182.2015.1058796.

[13] G. Evans, "Hold back the night: Nuit Blanche and all-night events in capital cities," Curr. Issues Tour., 2012, doi: 10.1080/13683500.2011.634893.

[14] H. K. Aytuğ and M. Mikaeili, "Evaluation of Hopa's Rural Tourism Potential in the Context of European Union Tourism Policy," Procedia Environ. Sci., 2017, doi: 10.1016/j.proenv.2017.03.039.

[15] A. T. Hsieh and J. Chang, "Shopping and tourist night markets in Taiwan," Tour. Manag., 2006, doi: 10.1016/j.tourman.2004.06.017.

[16] H. Farhan and K. Anwar, "The Tourism Development Strategy Based on Rural and Local Wisdom,” J. Sustain. Dev., 2016, doi: 10.5539/jsd.v9n3p170.

[17] R. Bromley, C. Thomas, and A. Millie, "Exploring safety concerns in the night-time city: Revitalising the evening economy," Town Plan. Rev., 2000, doi: 10.3828/tpr.71.1.rnk3336381678247.

[18] M. Bălan and C. Burghelea, "Rural Tourism and its Implication in the Development of the Fundata Village," Procedia - Soc. Behav. Sci., 2015, doi: 10.1016/j.sbspro.2015.03.393.

[19] J. Nofre, E. Giordano, A. Eldridge, J. C. Martins, and J. Sequera, "Tourism, nightlife and planning: challenges and opportunities for community liveability in La Barceloneta," Tour. Geogr., 2018, doi: 10.1080/14616688.2017.1375972.

[20] M. Markwick, "Valletta ECoC 2018 and cultural tourism development," J. Tour. Cult. Chang., 2018, doi: 10.1080/14766825.2017.1293674. 